\title{
EFL Teachers' Efforts in Developing Their Pedagogical Competence
}

\author{
Wulan Mayang Sari \\ State Islamic University of Raden Fatah Palembang \\ wulan@gmail.com \\ Amalia Hasanah \\ State Islamic University of Raden Fatah Palembang \\ amaliahasanah_uin@ radenfatah.ac.id \\ Eka Sartika \\ State Islamic University of Raden Fatah Palembang \\ ekasartika_uin@radenfatah.ac.id
}

\begin{abstract}
The aims of this study were to find out investigate what EFL teachers do to developing their pedagogical competence in teaching implementation. The participants of this study were English teachers in SMP Xaverius 3 Palembang. Qualitative method was used in this study. The data gained from interview was analyzed by using thematic analysis. The study applied purposive sampling. The result of the study showed that the English teachers join some activities and programs as the efforts of developing their pedagogical competence. To increase the knowledge of classroom management, teachers usually did induction programs. Teachers also should join many kind of seminars, workshops, short courses or teacher trainings related to teaching in order to develop their knowledge of teaching methods. Teachers can develop their knowledge of classroom assessment by joining seminars, workshop, reading books or articles, watching youtube, and using other platforms. Lesson study activities are used by teachers to help them making lesson plan.
\end{abstract}

Keywords: Pedagogical competence, teacher, education.

\section{A. Introduction}

Many experts have defined what teacher is. The teacher is the person who is capable of creating behavioral change in term of cognitive, psychomotor as well as affective domain (Mbise, 2008, p. 14). According to Senge (2000, p. 21), teacher is an expert who is capable of imparting knowledge that will help learners to build, identify and to acquire skills that will be used to face the challenges in life. Therefore, teacher is a person who has skills and knowledge and be able to influence their student. Considering with those descriptions, it is important for teachers to be competent.

Dengerink, Lunenberg, and Korthagen (2015, p. 27) have identified six roles of teacher, there are teacher of teachers, researchers, coach, curriculum developer, gatekeeper (responsible for admission to the teaching profession), and broker (responsible for the 
Jadila: Journal of Development and Innovation in Language and Literature Education

Publisher: Yayasan Karinosseff Muda Indonesia
E-ISSN: 2723-6900

P-ISSN: 2745-9578

Volume. 1 Number 2, 2021

Page: 57-72

connection between school and teacher education institute). The teacher's new role is undisputable in this modern times and social needs (Switala, 2012, p. 18). According to Switala (2012, p. 19), in that new role, teacher should support both the students and their parents, teacher should act as guides for their students and direct them in their individual processes of development, taking into considersation the challenges of the globalisation process. Teacher should organize classrooms, implement effective classroom pedagogy and work cooperatively with students. However, the teachers' knowledge of learning method is also an essential thing to be mastered. But sometimes, only few English teachers who figure out what the teaching method actually is.

Many Indonesian teachers have been found the lack of teaching competence although the role of teachers in the classroom is very significant. This has been observed by Bjork (2005, p. 22) and ascribed from the long tradition of teacher-centered teaching and rote learning in the Indonesian classroom. Teacher-centered class instruction is deeply embedded in Indonesian school settings; this type of instruction has become a part in the Indonesian school culture (Teuku, 2002, p. 14). This instruction method provides a little space for students to be creative. The teacher-centered classroom instruction is undemocratic because it fails to figure out students' dynamics and ignores students' contribution in the classroom.

The researcher experienced a different case when studying in Senior High School. The teacher of English focused only on the book instruction most of the time without try to develop and give clear explanations about the materials. Consequently, it made the learners feel bored to study English because the teachers do not teach creatively during the class. Therefore, it has two possibilities why teachers did not explain the materials and just gives assignments to do. First, the teachers perhaps understand the materials but do not know how to deliver it. Second, the teachers really do not know the materials moreover to explain it. If one of the problems is experienced by the teachers, it means that the teachersare not professional in teaching yet.

A professional teacher is a person who has educated and trained well. The national Indonesian curriculum was updated in 2013 and now requires high school teachers to help their learners demonstrate knowledge and skills relating to the generic structures, social functions, and language features of a range functional text types in English, including recounts, procedures, descriptions, and factual reports. Hence, the government requires English teachers not only to hold an educational degree, minimally a bachelor of education, 
Jadila: Journal of Development and Innovation in Language and Literature Education

Publisher: Yayasan Karinosseff Muda Indonesia
E-ISSN: 2723-6900

P-ISSN: 2745-9578

Volume. 1 Number 2, 2021

Page: 57-72

but also to possess educational quality and personal, social, professional, and pedagogical competencies. It is because the English teachers do not only deliver and transfer the materials to learners but also have to be a facilitator assisting them to learn optimally. Having a sufficient and appropriate quality could help Indonesia and the learners achieve the educational objectives mandated by the laws and regulations.

Among many requirements that a teacher of English must possess, the pedagogical content knowledge plays an important role in developing teacher expertise. Cooper argued that pedagogical competence refers to performance, knowledge and skill in teaching and learning, thus it includes teachers' capability to manage the teaching and learning process from the planning to the evaluation stage (Syahruddin, Ernawati, \& Ede, 2013, p. 214). Indonesian government policy and regulation defined teachers' pedagogical competence as the understanding of basic education, students, curriculum development, lesson plans, dialogical teaching and learning process, learning evaluation, and students' potential developments. According to Ryegard, Apelgren, and Olsson (2010), pedagogical competence is the ability in the management of students that includes an understanding of the student, designing and conducting learning, evaluation of learning outcomes, and the development of student to actualize various potentials.

Pedagogical knowledge should be mastered by every teacher for guiding and managing learning interactions in the classroom. Pedagogical competence consists of understanding students, basic principles in teaching, curriculum development, lesson plan, ICT mastery, students' potential development, teachers' talk, evaluation and reflective action (Permendiknas No.16 Tahun 2007). Pedagogical competence should be built by practicing in classroom setting that faces real problems and students with various characteristics. Teachers with good pedagogical competence can understand the difficulties experienced by students in learning material so that students can understand and be avoided from difficulties (Tsafe, 2013, p. 35). The effect of enchancing teacher pedagogical skills is generated gradually toward students, whereas when teachers improve pedagogical skills, students' achievement will also increase (Marzano, 2013, P. 14). So, it is very important for teachers to develop their pedagogical competence.

The researchers have taught in one of institution in Palembang. At that time, the researcher's students mostly come from the same school, Xaverius Palembang. The researcher realized that these students have high level and also so dominant in learning. 
Jadila: Journal of Development and Innovation in Language and Literature Education

Publisher: Yayasan Karinosseff Muda Indonesia
E-ISSN: 2723-6900

P-ISSN: 2745-9578

Volume. 1 Number 2, 2021

Page: 57-72

Moreover, when the researcher came to other branches outside Palembang, the researcher has heard so many opinions about this school. Even the students there want to continue their higher school in Xaverius. Xaverius becomes very popular there. So, the researcher did a preliminary study in Xaverius high school in Palembang.

The researcher wants to know why Xaverius become top rated and so popular even outside Palembang. By conducting the preliminary study there, the researcher found out that the teachers have good qualification in teaching. The teachers said that they usually attend some seminar or teaching training. And also the school facilitates the teachers so that all the teachers can develop their competence in teaching implementation. Therefore, all the students feel comfortable in learning process. Based on the preliminary study that has been conducted in SMP Xaverius 3 Palembang, most of the teachers have good knowledge of pedagogical content in teaching implementation in the classroom. The teachers have the ability such as classroom management, teaching methods, classroom assessment techniques, and lesson study. Hence, the researcher wants to know how the teachers can develop their pedagogical competence and what the efforts that they have done.

From the explanations and reasons stated previously, the researcher wants to obtain the data by conducting a research about English teachers' pedagogical competence. It will be carried out by the researcher to obtain the data in order to know the efforts of EFL teachers in developing their pedagogical competence. Finally, the researcher is interested in conducting a research entitled: "EFL Teachers' Efforts in Developing Their Pedagogical Competence in Teaching at SMP Xaverius 3 Palembang”,

\section{B. Literature Review}

\section{Concept of Pedagogical Competence}

In the teaching system, competencies are used to describe the ability of professionalism in which the ability to demonstrate the knowledge and the conceptualization in a higher level. Competence means the ability of perform a task (Beauchamp, 1991, p. 31). According to the Law number 14 year 2005 about teacher and lecturer in section 1, subsection 10, mentioned "Competence (capability) is a set of knowledge, competence, and behavior that must be belonging to, inspired, mastered by teacher or lecturer in carrying out the task of professionalism". According to Weinert (2001, p. 56), competence has been defined as general cognitive ability, specialized cognitive skills, competence-performance 
Jadila: Journal of Development and Innovation in Language and Literature Education

Publisher: Yayasan Karinosseff Muda Indonesia
E-ISSN: 2723-6900

P-ISSN: 2745-9578

Volume. 1 Number 2, 2021

Page: 57-72

model, modified competence-performance model, objective and subjective self-concepts, motivated action tendencies, action competence, key competencies and meta-competencies. From the definitions above, competence is a set of mastery of abilities, skills, values, and attitudes that must be owned and controlled by the teacher of English.

According to Gordon, as quoted by Qodriyah (2016, p. 8), there are six aspects or domains contained in the concept of competence, as follows:

1. Knowledge, is an awareness in cognitive field, for example a teacher knows how to identify learning needs, and how to perform the learning of the students according to their needs.

2. Comprehension (understanding), is the depth of cognitive and affective owned by individuals, fro example, a teacher who would carry out the study must have a good understanding of the characteristics and circumstances of learners.

3. Ability (skill), is something that is owned by an individual to perform a task or job assigned to him, such as the ability of teachers to choose and create simple props to provide ease of learning to learners.

4. Values, is a standard of behavior that has been believed and psychologycally been fused in a person, for example, the standard behavior of teachers in learning (honestly, openess, democratic and others).

5. Attitude, is feeling (happy, unhappy, likes, dislike) or a reaction to a stimulus that comes from outside, a reaction to the economic crisis, the feeling of the salary increase, and others.

6. Interest, is the tendency of a person to perform an act, such as interests to do something or learn something.

\section{Concept of Teacher}

Teachers play an important role in what they do, and how they do in developing their own professional knowledge and practice (Loughran, 2006, p. 4). A good teacher is the most determinant of the student' achievement in the classroom (Hayes, 2003, p. 54). The essential aspects to become a good teacher is having basic skills. It will help teachers to develop the courses and methods.

Teacher can be called as a competent teacher if they have a good competence and performance. It is because of both competence and performance are the two important factors 
Jadila: Journal of Development and Innovation in Language and Literature Education

Publisher: Yayasan Karinosseff Muda Indonesia
E-ISSN: 2723-6900

P-ISSN: 2745-9578

Volume. 1 Number 2, 2021

Page: 57-72

that EFL teachers needed to conducting successful classroom instructions (Brown, 2001, p. 84). According to Scrivener (2005, p. 79), teacher are required to have certain organisational skills and techniques in managing multitude of tasks and situations that can ocuur at any time in the classroom. Scrivener makes a very valid point when he said that teachers have to be able to look at and read classroom events as they occur and think of possible options (2005, p. 80). Teacher quality is an important factor in determining gains in student achievement, even after accounting for prior student learning and family background characteristics.

The development of a quality relationship between teachers and their students, good communication, and keeping children on task are the key components that affect success in classroom management. If teacher are able to run the classroom in an effective way, it helps students to be successful in their learning (Evertson, 2006, p. 65). Gower, Phillips, and Walters $(2008$, p. 21) emphasize that teachers have to consider the balance between being friendly and maintaining discipline. It is basic that teachers discover ways of creating connections with all their students and building a sense community within the classroom.

The quality of teachers and teaching can be conceptualized and measured in many ways (Chang et al., 2014). One approach focuses principally on teacher productivity, perhaps best assessed by general classroom performance and specific teacher practices. In recent decades, greater attention has been given to such practices, in part because of landmark studies that found classroom effects to be greater than school effects.

\section{Education in Indonesia}

Education plays an important role in the development of a country. If a country does not have proper education, it may be left behind by other countries which support education. The development of a country can be determined by whether its citizens have good education or not. The better the quality of education that a country has, the faster it is likely to develop.

Education and skills are central to Indonesia's growth prospects in the next decade (Asian Development Bank, 2015, p. 19). Education become a central of Indonesia's growth prospects in the future. Based on Asian Development Bank (2015, p. 19), "PISA shows that Indonesian students are performing some three years behind the OECD average. Over $50 \%$ of Indonesian fifteen year olds do not master basic skills in reading or mathematics. Raising performance in Indonesian education is crucial to meeting the challenge of reaching a high 
Jadila: Journal of Development and Innovation in Language and Literature Education

Publisher: Yayasan Karinosseff Muda Indonesia
E-ISSN: 2723-6900

P-ISSN: 2745-9578

Volume. 1 Number 2, 2021

Page: 57-72

income status". Indonesia should concern about improving the learning outcomes and enable students to form core skills and understanding.

Based on the researcher's experience, the education system in Indonesia still uses the one-way communication. The teachers stand in front of in the class and explain all the materials, while the students just sit down on their seats and listen to the teachers. One-way communication has negative effects on the students. They become unconfident to share their opinions or even ask a question. The government should improve this education to a better one. Two-way communication is considered as a better way in teaching method. The development of technology contributes much impact on the education. It can be very useful for many people to get the education. Education is essential in human's life. As time goes by, system of education changes dynamically following the needs of human beings.

\section{Research Method}

\section{Research design}

In doing this research, the researcher applied a qualitative method. Qualitative research can be used for descriptive purpose. The purpose of descriptive qualitative research is to become more familiar with phenomena, to gain new insight, and to formulate a more specific research problem. According to Creswell (2012), the historic origin for qualitative research design comes from anthropology, sociology, the humanities and evaluation. This method does not search for something or make prediction, but it only describes the situations and phenomenon.

This research used interview as the instrument. The researcher found out about EFL teachers' efforts in developing their pedagogical competence in teaching at SMP Xaverius 3 Palembang.

\section{Research site and participants}

This research was conducted at SMP Xaverius 3 in Palembang. Purposeful sampling was used in this study. According to Creswell (2007, p. 125), purposeful sampling is synonymous with qualitative research. This is because the researcher can select participants and research sites that are associated with the phenomenon and resesarch problem being studied. According to Creswell (2007, p. 127), there are some types of this sampling, one of them is criterion. The purpose of criterion sampling is all cases that meet some criterion. The 
Jadila: Journal of Development and Innovation in Language and Literature Education

Publisher: Yayasan Karinosseff Muda Indonesia
E-ISSN: 2723-6900

P-ISSN: 2745-9578

Volume. 1 Number 2, 2021

Page: 57-72

researcher used this sampling because the participants were selected based on some purpose. The participants that were chosen can meet certain criteria from this study. The researcher took English teachers at SMP Xaverius 3 Palembang. The researcher took the English teachers based on the achievement, performance and good experience in teaching.

\section{Data collection and analysis}

In order to answer the research problems and questions related to kinds of activities done by professional EFL teachers and how those activities help them to develop their pedagogical competence, the data was obtained from interview session with the research participants. While conducting the interview, the researcher used a semi-structured interview and one-on-one interview type. Semi-structured interviews are a widely used technique in development research. Semi-structured interviews focus on specific themes but cover them in a conversational style (Raworth, sweetman, Narayan, Rowlands, \& Hopkins, 2012). One-onone interview is a data collection process in which the researcher asks questions and records answers from only one participant in the study at a time (Creswell, 2012, p. 218).

In order to analyze the qualitative data gained from the nterview of the activities that have been done by the teachers to develop their pedagogical competence, thematic analysis was used in this study.

\section{Results and Discussion}

\section{Results}

This study aimed to identify what EFL teachers' efforts in developing their pedagogical competence in teaching at SMP Xaverius 3 Palembang using interview.After collecting data from interviewing teachers, the researcher identified and analyzed the activities done by teachers as the efforts of developing their pedagogical competence in teaching implementation. The findings are described as follows based on the themes and codes:

Table 1. Kinds of activities which have been done by teachers to develop their pedagogical competence

\begin{tabular}{ll}
\hline \multicolumn{1}{c}{ Themes } & \multicolumn{1}{c}{ Codes } \\
\hline Induction programs & Teachers joined some induction programs such as \\
& peer work with other new teachers, seminars and \\
& webinar as the efforts for them to improve their \\
\hline
\end{tabular}


Jadila: Journal of Development and Innovation in Language and Literature Education

Publisher: Yayasan Karinosseff Muda Indonesia
E-ISSN: 2723-6900

P-ISSN: 2745-9578

Volume. 1 Number 2, 2021

Page: 57-72

knowledge in managing the classroom.

Workshops Teachers joined some workshops that dealing with various teaching methods to create interactive learning, deliver and share the materials easily. By joining those programs, teachers can increase their knowledge of teaching methods.

Classroom assessment seminars Teachers joined some seminar about how to assess their students as one of the effort for them to develop their knowledge in classroom assessment, because it is important to have various ways in assessing the students.

Lesson study activities

Teachers joined lesson study activities such as, group discussion, designing lesson plan, implementing the lesson, revising the lesson plan, evaluating the teaching process, and sharing the result with other teachers. Teachers thought that lesson study activities are really helpful and important because without sharing, there is no improvement.

\section{Induction Programs}

Both teacher 1 and 2 have joined some induction program. The induction programs that they have joined are seminars and webinars. Teacher 1 have joined seminar conducted by Cambridge about "How to engage with kids and teenagers in fun learning", however teacher 2 did not join that program because only one teacher became the representative from that school. Teacher 2 explained that after teacher 1 joined that Cambridge seminar, teacher 1 was asked to deliver and share to other teachers, especially teacher 2 as an English teacher, about what she got from the seminar. Teacher 1 and teacher 2 said that those activities sometimes done once or twice in a semester. When the researcher asked about other activities that they have joined, recently teacher 1 and teacher 2 mentioned that they joined Macmillan webinar twice a month or sometimes three times a month start April, six months ago. Because of the current situation, the seminars was turned into webinars. The next question that was asked by the researcher is "Are those activities useful for teacher and why?", teacher 1 said "Before joining these kinds of activities, I felt hard to teach sometimes but after joining some seminars and webinars, it refreshes my mind and more focus in managing the classroom". Teacher 2 answered "Yes they are. Those activities are really helpful and useful because I am able to improve myself in managing the classroom. Before joining these kinds of programs, sometimes I felt afraid". In conclution, from the answers above, the researcher can conclude 
Jadila: Journal of Development and Innovation in Language and Literature Education

Publisher: Yayasan Karinosseff Muda Indonesia
E-ISSN: 2723-6900

P-ISSN: 2745-9578

Volume. 1 Number 2, 2021

Page: 57-72

that induction activities (activities that support the introduction into the teaching profession, e.g. peer work with other new teachers, mentoring by experienced teachers, seminars etc.) can be an important effort for teachers to develop their knowledge in classroom management.

\section{Workshops}

In increasing the knowledge of teaching methods, the researcher asked "Have you ever join workshops or seminars about teaching-related topic?". Teacher 1 said that she has ever joined workshops from Periplus and Mentari Book. Periplus provided some fairytales books, interactive learning books for kids and also up-to-date news for teenagers that are suitable for teenagers. Teacher 1 mentioned that the teaching techniques from Periplus taught her about teaching methods for kids and teenagers from fairytales books. Mentari Book workshop that teacher 1 joined is also about teaching methods. Teacher 2 that he joined the seminar from Erlangga Publisher. Then, the researcher asked whether the teachers have joined short courses or teacher training dealing with various teaching methods. Both teacher 1 and teacher 2 said that they usually joined the teacher training from the institution together with other teachers. Teacher 1 added "Do not be a teacher but be a friend in the classroom". She just remember that in one of the seminar, that she have joined, they said that teachers have to be the same as the students. To be a good teacher, we have to be the same as the students, not the knowledge but to be in the same level as them so there is no gap between the teachers and the students. It will make the students feel more confortable to speak in the classroom and to do whatever they want to do in the classroom (in a good way). It also makes the teachers feel easier in delivering the materials and sharing the knowledge also it is so easy for the students to accept the materials. The last time teacher 1 and teacher 2 joined the activity was in September this year. After joining the workshops, both teacher 1 and teacher 2 feel there are no any difficulties in elaborating and encouraging the students. For example, when the institution asked her to teach very young kids, that is not a big deal for her. When they are asked to teach teenagers, it is not a problem. When the institution asked them to teach English for Specific Purpose such as employee and adolescences, it is okay for them since they have so many methodologies and techniques in teaching.

\section{Classroom Assessment Seminar}


Jadila: Journal of Development and Innovation in Language and Literature Education

Publisher: Yayasan Karinosseff Muda Indonesia
E-ISSN: 2723-6900

P-ISSN: 2745-9578

Volume. 1 Number 2, 2021

Page: 57-72

In this stage, the researcher asked "Have you ever join classroom assessment workshops or seminars for teacher?". Teacher 1 and teacher 2 replied that they have joined classroom assessment seminars. It is from Cambridge Examination Assessment seminar. It is about how important to assess students in many ways. Teacher 1 and teacher 2 said that it is important for teachers to join this kind of activity. Teacher 1 mentioned "I have a new standard and new way of assessing students' ability". It means that not only by doing multiple choice or translation or listening to the passages and answering questions or writing about any topic, but there are many kinds of assessment related to English that we can do as a teacher for giving to the students. Sometimes the students do not realise or recognise if it is an examination, and they do it, and we know their skills. And when the students realise that it is an examination, they will feel easy and not afraid of examination. It makes them study hard and harder and their score wil be higher too. Beside joining the seminars, teacher 1 and teacher 2 use video from youtube and other platforms. Teacher 1 likes to watch videos learning, such as ABCYa.com (for kids), chocochoo, Papa's English etc. Teacher 2 also watched videos but mostly reads books. There are three books usually read by teacher 2 , general book for teaching, teachers' manual book and English on Sky book.In summary, teacher 1 and teacher 2 develop their knowledge of classroom assessment by joining workshops and seminar.

\section{Lesson Study Activities}

Teacher 1 and teacher 2 have participated in lesson study activities to increase their pedagogical competence. Lesson study activities such as, group discussion, designing lesson plan, implementing the lesson, revising the lesson plan, evaluating the teaching process, and sharing the result with other teachers. Both teacher 1 and teacher 2 answered that they participated on such activities. Teacher 1 and teacher 2 do a control of the teaching and learning English in the school. Teacher 2 mentioned that there is a MGMP (Musyawarah Guru Mata Pelajaran) Xaverius. It is for all of the teachers in Xaverius institution. The MGMP is held once in a month. In that meeting, all teachers have discussion formally about how to design lesson plan, implement the lesson in te classroom, revise the lesson plan if necessary, evaluate the teaching process past one month, and also share the result with other teachers. Teacher 1 said "Beside having formal discussion with the institution, we usually having discussion with colleagues in this school only as much as we can at least twice in a 
Jadila: Journal of Development and Innovation in Language and Literature Education

Publisher: Yayasan Karinosseff Muda Indonesia
E-ISSN: 2723-6900

P-ISSN: 2745-9578

Volume. 1 Number 2, 2021

Page: 57-72

week and sometimes more than that". In designing lesson plan, teacher 1 use some sources such as the material that she got from the seminars and workshops, books and articles, since they use Macmillan Education Everywhere aplication for classes so she uses that platform to make the lesson plan. Teacher 1 has teamwork with her colleagues. They usually plan the new teaching aids and also we have a discussion about what should we do for measuring their students' capability and skills. Sometimes teacher 1 also observing the learning process and having discussions after learning for improving the next learning process. Based on the answers above, both teacher 1 and teacher 2 think that lesson study activities are really helpful and importantbecause without sharing, there is no improvement.

\section{Discussion}

From analizing the data using thematic analysis, the teachers used all the activities that related to develop their pedagogical competence. Those activities are also used by some previous researchers and would be discussed more in detail.

Based on the results that the researcher got, the overall findings have strengthened the previous studies concerning kind of activities done by EFL teachers as the efforts of developing their pedagogical competence in relation to their teaching implementation. From the kinds of activities undertaken by the participants to develop their knowledge of pedagogical content, the most common activities are attending seminars or webinars, workshops, having informal discussion with colleagues, join teamwork, using the internet as well as books and articles.The activities dealing with attending seminars, webinars, workshop, short courses, and teacher training has also supported the previous studies regarding the importance of those activities for teachers' pedagogical competence (Macias, 2013; Syahrudin et al, 2013; Janah, 2016; Syahrul, 2016; Aimah et al, 2017; Irmawati, 2017). Seminars and workshops by inviting some experts to be the trainers or speakers as one of the contributive elements in the way how teachers learn is in the line with what is stated by Carlisle and Berebitsky (2011). According to Carlisle and Berebitsky (2011), the presence of the experts can help teachers to broaden their knowledge relates to their problem solving in teaching practice. Still in line with this, Madya (2007); Richards and Farrel (2005); Priajana (2015) have shown that such kind of workshops and teacher training are often done and needed by teachers as the efforts for developing their teaching competence. 
Jadila: Journal of Development and Innovation in Language and Literature Education

Publisher: Yayasan Karinosseff Muda Indonesia
E-ISSN: 2723-6900

P-ISSN: 2745-9578

Volume. 1 Number 2, 2021

Page: 57-72

Having discussion and joining teamwork with colleagues are similar to what is stated by Hismanoglu (2010) and Anif et al. (2019) who say that by having group discussion is also the effective way in developing teachers' pedagogical competence.Therefore, these activities provide meaningful feedback to the classroom practices.

The finding which showed that the participants did lesson study activitiesis in the same line as Emiliasari (2018) who states the lesson study activities can improve the quality of teaching and also teachers' pedagogical competence that is important to be improved. Emiliasari (2018) also states that by conducting lesson study, there are so many positive changes. Futhermore, the findings shows that the participants use internet, books, and article to design lesson plans and materials. This statement is supported by Macia and Garcia (2016) who say that learning has become open through the use of internet and platform to enhance the teachers' proffesional growth.

\section{E. Conclusion and Recommendations}

Based on the results of the interview, it can be concluded that teachers join some activities and programs as the efforts of developing their pedagogical competence.

To increase the knowledge of classroom management, teachers usually did induction programs. Induction program itself means some activities that support teachers introduction into the teaching profession such as, peer work with other new teachers, mentoring by experienced teachers, seminars etc. Those kinds of activities proved to be very beneficial for teachers.

Teachers also should join many kind of seminars, workshops, short courses or teacher trainings related to teaching in order to develop their knowledge of teaching methods. By joining those programs, teachers can feel more confident and comfortable delivering the materials to their students and students can get the knowledge easier as well.

The knowledge of classroom assessment is essential for teachers too. The way how teachers assess their students are different. Especially in English lesson, teachers do not only assess their students from multiple choice or writing, but also from daily conversation, daily performance, simple quiz, and many creative ways. Teachers can develop their knowledge of classroom assessment by joining seminars, workshop, reading books or articles, watching youtube, and using other platforms. 
Jadila: Journal of Development and Innovation in Language and Literature Education

Publisher: Yayasan Karinosseff Muda Indonesia
E-ISSN: 2723-6900

P-ISSN: 2745-9578

Volume. 1 Number 2, 2021

Page: 57-72

Lesson study activities are such important ways for teacher to planing their lesson. Group discussion, designing lesson plan, implementing the lesson, revising the lesson plan, evaluating the teaching process, and sharing the result with other teachers are kinds of lesson study activities. Teachers usually join teachers association forum for having group discussion. MGMP (Musyawarah Guru Mata Pelajaran) is one of the teacher association forum. Based on the interview, teachers said that without sharing, there is no improvement.

This study focused on EFL teachers' efforts in developing their pedagogical competence in teaching. Based on the results, the researcher found out that teachers join seminars, webinars, workshops, teachers training, and teacher association forum as their efforts in increasing their knowledge.

The knowledge of classroom management, knowledge of teaching methods, knowledge of classroom assessment, and lesson planing and evaluation adaptability in the classroom are very important for teacher. So, the researcher suggests that teachers have to join any kinds of programs and activities related to those competence. By joining the programs, teachers can develop their pedagogical competence in teaching. It will make them easily to deliver the material and students feel fun when they study English. Because studying language should be fun.

\section{References}

Aimah, S., Ifadah, M., \& Bharati, D. A. L. (2017). Building teachers' pedagogical competence and teaching improvement through lesson study. Arab world English journal (AWEJ), 8(1), 66-78.

Anderson, L. W. (2004). Increasing teacher effectiveness. UNESCO, International Institute for Educational Planning.

Anif, S., Sutama., Prayitno, H. J., \& Idrus, N. B. M. (2019). Effectiveness of pedagogical competence: A development model through association of biology teachers' forum. Journal pendidikan IPA Indonesia, 8(1), 22-31.

Apelgren, K., \&Giertz, B. (2010). Pedagogical competence - a key to pedagogical development and quality in higher education. Uppsala University.

Asian Development Bank. (2015). Education in Indonesia: rising to the challenge. OECD Publishing.

Beauchamp, T. L. (1991). Competency: a study of informal competency determination in primary care. In Cutter, M. \& Shelp, E (Eds.), Re-examining concept of competence $\left(2^{\text {nd }}\right.$ ed., pp. 50). Klumer Academic Publisher

Bjork, C. (2005). Indonesian education teachers, schools and central bureaucracy. Taylor \& Francis Group, LLC. 
Braun, V., \& Clarke, V. (2006). Using thematic analysis in psychology. Qualitative Research in Psychology. (Online). http://eprints.uwe.ac.uk.

Brown, H. D. (2001). Teaching by principles. An interactive approach to language pedagogy $\left(2^{\text {nd }}\right.$ ed $)$. Pearson Edition.

Carlisle, M. K., \& Berebitsky, D. (2011). Literacy coaching as a component of professional development. Journal of reading and writing, 24, 773-800.

Chang, M. C., Shaeffer, S., Al-Samarrai, S.,Ragatz, A, B., de Ree, J., \& Stevenson, R. (2014). Teacher reform in Indonesia. The role of politics and evidence in policy making. The World Bank.

Creswell, J. W. (2007). Qualitative inquiry and research design $\left(2^{\text {nd }}\right.$ Ed). Sage Publications.

Creswell, J. W. (2012). Research design: qualitative, quantitative and mixed methods approaches $\left(3^{\text {rd }}\right.$ Ed). Sage Publications.

Darling-Hammond, L., \& Bransford, J (2005). Preparing teacher for a changing world: what teacher should learn and be able to do. Jossey-Bass.

Dengerink, J., Lunenberg, M., \& Korthagen, F. (2015). The professional teachers educator: six roles. Beitragezurlehrerinnen- UND lehrerbildung, 33(3), 1-11.

Emiliasari, R, N. (2018). An analysis of teachers' pedagogical competence in lesson study of MGMP SMP Majalengka. ELTIN journal, 6(1), 22-33.

Evertson, C. M., \& Weinstein, C. S. (Eds.) (2006). Handbook of classroom management. Research, practice, and contemporary issues. Larence Erlbaum Associates, Inc.

Gower, R., Phillips, D., \& Walters, S. (2005). Teaching practice. A handbook for teachers in training. Macmillan.

Hayes, C. (2003). Teacher professional development: a primer for parents and community members.

Hismanoglu, M. (2010). Effective professional development strategies of English language teachers. Procedia social and behavioral sciences, 2, 990-995.

Irmawati, D, K., Widiati, U., \& Cahyono, B, Y. (2017). How do Indonesian professional English teachers develop their pedagogical competence in teaching implementation? Arab world English journal (AWEJ), 8(2), 293-307.

Janah, I. (2016). The effect of teacher's pedagogical competence toward Student's learning achievement in Qur'an hadith subject class VIII at MTs Ma'Arif NU 1 Purwojati Banyumas. IAIN Purwokerto.

Loughran, J. (2006). Developing a pedagogy of teacher education: understanding teaching and learning about teaching.

Macias, D. F. (2013). An exploration of EFL teachers' awareness of the sources of pedagogical knowledge in a teacher education program. Issues in Teachers' Professional Devvelopment, 15(2), 1-14.

Madya, S. (2007). Empowering EFL teachers to achieve professional autonomy. A paper presented at the $4^{\text {th }}$ JETA international conference.

Marzano, R, J., \&Toth, M, D. (2013). Teacher evaluation that makes a difference: A new model for teacher growth and student achievement. ASCD.

Mbise, A. S. (2008). Early childhood service delivery mapping and baseline study in Bagamoyo, Hai, Magu and Mtwara: Summary of findings and recommendations. Dares Salaam: Ministry of Education and Vocation Training.

McCaughtry, N., Kulinna, P. H., Cothran, D., Martin, J., and Faust, R. (2005). Teachers mentoring teachers: a view over time. Journal of Teaching in Physical Education, 24, 326-343. 
Meiers, M. (2007). Teacher professional learning, teaching practice and student learning outcomes: important issues. In T. Townsend \& R. Bates (Eds.), Handbook of teacher education: globalization, standards and professionalism in times of change, pp. 409-414. Springer.

Nunn, P. (2004). Principles of education. Discovery Publishing House.

Panda, S. (2014). Enriching pedagogical competency of science teachers through simulation class in pre service teacher education: an action research in college of teacher education. IOSR Journal of Research \& Method in Education (IOSR-JRME), 4, 25-29.

Prijana, N. (2015). Professional development of exemplary EFL teachers. (Unpublished Dissertation). Universitas Negeri Malang.

Qodriyah, W, R. (2016). An analysis of teachers'pedagogical competence in teaching English for young learners at NARA Islamic School Cirebon. IAIN Syekh Nurjati.

Raworth, K., Sweetman, C., Narayan, S., Rowlands, J., \& Hopkins, A. (2012). Conducting semi-structured interviews. Oxfam GB.

Richards, J., \& Farrell, T. (2005). Professional development for language teachers: Strategies for teaching learning. Cambridge University Press.

Ryegard, A. (2010). A swedish perspective in pedagogical competence. Uppsala University.

Schneckenberg, D., \&Wildt, J. (2010). Understanding the concept of competence for academic staff. Available at http://www.ecompetence.info/uploads/media/ch3.pdf.

Scrivener, J. (2005). Learning teaching ( $\left.2^{\text {nd }} e d\right)$. Macmillan Publisher

Senge. (2000). School that learn. Double Day Publishing Group.

Smith, M, K. (2012). What is pedagogy? In Encyclopaedia of Informal Education. Available at: http://infed.org/mobi/what-is-teaching/.

Suciu, A, I., \& Mata, L. (2015). Pedagogical competences - the key to efficient education. International Online Journal of Educational Science, 3(2), 411-423.

Switala, E, S. (2012). The professional role of a teacher in the era of gloalozation on the example of Poland. Educational reasearch ejounal university of alicante, 1(1), 61-70.

Syahruddin.,Ernawati, A., and Ede, M, N. (2013). Teachers' pedagogical competence in school-based management. Journal of Education and Learning, 7, 213-218.

Syahrul, M. (2016). The analysis of pedagogical competence of the English teachers' of the second grade students at MTs Negeri 1 Jeneponto in teaching English. UIN Alauddin.

Tsafe, A, K. (2013). Scientific of pure and applied science, 2. 35

Undang-Undang Republik Indonesia Nomor 14 tahun 2005. Tentang Guru dan Dosen. Citra Umbara.

Voss, T., Kunter., \& Baumert, J. (2011). Assessing teacher candidates' general pedagogical/psychological knowledge: Test construction and validation. Journal of education psychology, 103, 952-969.

Weiner, F, E. (2001). Concept of competence: a conceptual clarification, in: D. S. Rynchen and L. H. Salganik (Eds) Defining and selecting key competencies, pp. 45-66 (Gottingen: Hogrefe).

Zulfikar, T. (2009). The making of Indonesian education: an overview on empowering Indonesian teachers. Journal of Indonesian Social Sciences and Humanities, 2, 13-39. 